\title{
Moisture transport and intraseasonal variability in the South America monsoon system
}

\author{
Leila M. V. Carvalho • Ana E. Silva • \\ Charles Jones • Brant Liebmann • \\ Pedro L. Silva Dias • Humberto R. Rocha
}

Received: 1 October 2009/Accepted: 22 March 2010/Published online: 14 April 2010

(C) The Author(s) 2010. This article is published with open access at Springerlink.com

\begin{abstract}
This paper examines moisture transport on intraseasonal timescales over the continent and over the South Atlantic convergence zone (SACZ) during the South America (SA) summer monsoon. Combined Empirical Orthogonal Function analysis (EOFc) of Global Precipitation Climatology Project pentad precipitation, specific humidity, air temperature, zonal and meridional winds at $850 \mathrm{hPa}$ (NCEP/NCAR reanalysis) are performed to identify the large-scale variability of the South America monsoon system and the SACZ. The first EOFc was used as a large-scale index for the South American monsoon (LISAM), whereas the second EOFc characterized the SACZ. LISAM (SACZ) index showed spectral variance on 30-90 (15-20) days and were both band filtered (10100 days). Intraseasonal wet anomalies were defined when LISAM and SACZ anomalies were above the 75th percentile of their respective distribution. LISAM and SACZ wet events were examined independently of each other and when they occur simultaneously. LISAM wet events were
\end{abstract}

L. M. V. Carvalho $(\bowtie)$

Department of Geography, University of California Santa

Barbara, Santa Barbara, CA 93106, USA

e-mail: leila@icess.ucsb.edu

L. M. V. Carvalho - A. E. Silva · P. L. Silva Dias · H. R. Rocha Department of Atmospheric Sciences, University of Sao Paulo, São Paulo, Brazil

L. M. V. Carvalho $\cdot$ C. Jones

Institute for Computational Earth System Sciences,

University of California Santa Barbara, Santa Barbara, CA, USA

B. Liebmann

CIRES Climate Diagnostics Center, Boulder, CO, USA

P. L. Silva Dias

National Laboratory for Scientific Computing, Petrópolis, Brazil observed with the amplification of wave activity in the Northern Hemisphere and the enhancement of northwesterly cross-equatorial moisture transport over tropical continental SA. Enhanced SACZ was observed with moisture transport from the extratropics of the Southern Hemisphere. Simultaneous LISAM and SACZ wet events are associated with cross-equatorial moisture transport along with moisture transport from Subtropical Southwestern Atlantic.

\section{Introduction}

The South American monsoon system (SAMS) is characterized by pronounced seasonality in the rainfall with the wet season in the austral summer and a dry season in the austral winter (Zhou and Lau 1998; Vera et al. 2006). Unlike the Asian monsoon there is no reversal of the mean surface wind. Nevertheless, the seasonal reversal of the large-scale circulation over SA resembles those of a monsoon system when the annual mean is removed (Zhou and Lau 1998). Other monsoon like features are observed such as the Bolivian High (Silva Dias et al. 1983), the stretching of the of the atmosphere column and conversion of low-level potential energy into upper-level divergent kinetic energy, and the interaction between divergent and rotational winds at the upper level that transform divergent kinetic energy into rotational kinetic energy (Wang and $\mathrm{Fu}$ 2002). Other important features of SAMS are the Northeast trough (Silva Dias et al. 1983; Lenters and Cook 1997), the low level Gran-Chaco low (Gandu and Silva Dias 1998) and the South Atlantic convergence zone (SACZ) (Kodama 1992).

The SACZ is the most significant feature of cloudiness and precipitation in the wet season over eastern Tropical 
South America and Southwestern Atlantic. It is characterized by a northwest-southeast persistent cloud band associated with low level convergence of winds and moisture (Kodama 1992). Numerical modeling studies have shown that the adiabatic heating in the Amazon Basin during the summer monsoon induces a regional tropospheric circulation that supports the NW/SE oriented low level convergence that maintains the continental component of the SACZ (Figueroa et al. 1995; Gandu and Silva Dias 1998). In addition, the SACZ is characterized by large spatial and temporal variability that depends on the interplay of phenomena on a broad range of scales (Carvalho et al. 2002a, b). Moreover, the intensification and weakening of the SACZ and its extension toward subtropical southwest Atlantic Ocean is strongly modulated by intraseasonal activity (NoguesPaegle and Mo 1997; Liebmann et al. 1999; Carvalho et al. 2004; Muza et al. 2009). The variability of the SACZ and its extent toward the continent and compensating subsidence over southern Brazil, Northeast Argentina and Uruguay (Nogues-Paegle and Mo 1997; Liebmann et al. 1999; Gandu and Silva Dias 1998; Figueroa et al. 1995) affect densely populated regions of southeastern South America and important agricultural poles and play a fundamental role in the hydrological cycle in these regions (Liebmann et al. 2001; Carvalho et al. 2002a).

The onset of intense convective activity and heavy precipitation over most of the Amazon, central and southeastern Brazil in the present climate is between October and November; it peaks in the austral summer (December-February) and the end of the rainy season over central and southeast Brazil is between the end of March and mid-April as intense precipitation gradually migrates from the south Amazon and central Brazil toward the equator (Kousky 1988; Horel et al. 1989; Marengo et al. 2001; Gan et al. 2004; Vera et al. 2006; Silva and Carvalho 2007; Bombardi and Carvalho 2009). Coupled atmosphere-ocean and land interactions modulate variations of SAMS on a broad range of timescales (Barreiro et al. 2002; Grimm 2003; Chaves and Nobre 2004; De Almeida et al. 2007; Misra 2008).

An important characteristic of SAMS is the frequent and persistent active and inactive (or "break") periods in the intensity of rainfall. Tropical intraseasonal oscillations have been found to strongly modulate these active and break periods with impacts in circulation (Casarin and Kousky 1986; Silva Dias and Marengo 1999; Jones and Carvalho 2002), mesoscale activity (Carvalho et al. 2002b; Petersen et al. 2002), extreme precipitation (Carvalho et al. 2004) and the seesaw of wet and dry periods over eastern South America (Nogues-Paegle and Mo 1997; Muza et al. 2009).
Changes in circulation caused by intraseasonal oscillations have important impacts on moisture transport and water balance in the monsoon region. Herdies et al. (2002) examined the moisture budget over several areas of tropical and subtropical South America during times characterized by the presence of the SACZ and times with no SACZ (NSACZ) during the 1999 January-February TRMM-LBA campaign (Avissar et al. 2002). They verified that during SACZ (NSCZ) conditions strong (weak) convergence is observed over the Amazon basin with divergence (convergence) over southwestern Brazil, northern Argentina and Paraguay. They showed that during the active phase of the SACZ strong moisture flow from the Atlantic Ocean entered South America and is funneled to southeastern Brazil. These events are accompanied by strong convergence in the Amazon basin, central eastern and southeastern Brazil.

The objectives of the present study are multiple. We propose the use of a large-scale index for the South America monsoon (LISAM; Silva and Carvalho 2007) to characterize the spatial-temporal features of the SAMS. Similar methodology will be used to identify the SACZ. The characterization of the SACZ as an independent feature of the continental component of the SAMS helps in understanding the mechanisms associated with moisture transport and ultimately its variations over time. In addition we will examine moisture transport during the occurrence of intraseasonal oscillations that affect SAMS and the SACZ. Our goal is to provide a large-scale analysis of the moisture fluxes during wet regimes. This study is organized as follows. Section 2 discusses datasets used in this study. Section 3 proposes a methodology to distinguish the continental versus oceanic activity of SAMS. Section 4 examines separately continental and oceanic activity in association with SAMS. Section 5 shows the importance of wave activity in the southern and northern hemisphere in modulating moisture fluxes and precipitation. Section 6 discusses the main conclusions.

\section{Data}

The present study examines intraseasonal variations in SAMS and SACZ during the SH wet season (DecemberFebruary). This analysis extends from 1979 to 2007. The datasets examined in this study are pentad (5-day average) precipitation estimates from the Global Precipitation Climatology Project (GPCP) (Xie et al. 2003), specific humidity $(q)$, air temperature $(T)$, zonal $(u)$ and meridional $(v)$ wind components, pressure $(p)$ from the National Centers for Environmental Prediction/National Center for Atmospheric Research (NCEP/NCAR) (Kalnay et al. 1996) with 2.5 latitude and longitude degrees resolution. 


\section{Characterization of SAMS and SACZ}

To characterize the monsoon regime a large-scale monsoon index was obtained by the method discussed in Silva and Carvalho (2007). To do so a combined EOF analysis $(\mathrm{EOFc})$ was performed using anomalies (climatological annual mean removed) of the following variables: GPCP estimates, $q, v, u$, and $T(850 \mathrm{hPa})$. The first combined EOFc mode (EOFc-1), which explains $24 \%$ of the total variance, represents the seasonal covariability of the most important variables that have been related to SAMS (Zhou and Lau 1998; Gan et al. 2006). Silva and Carvalho (2007) demonstrated that the EOFc-1 time coefficient can be used as a large-scale South America Monsoon index (henceforth LISAM) to identify the onset, demise, intensity and intraseasonal variation of SAMS. Moreover, seasonal (OctoberMarch) spectral analysis of LISAM shows a peak on intraseasonal time-scales between 30 and 90 days (Silva and Carvalho 2007). This peak is consistent with the Madden-Julian oscillation (Madden and Julian 1994), which is known to play an important role in modulating convection over eastern SA during the summer (Carvalho et al. 2004; Jones et al. 2004a, b). Silva and Carvalho (2007) showed that positive (negative) anomalies of LISAM are related to active (break) phases of the monsoon and respective patterns of enhanced (suppressed) precipitation and westerly (easterly) low-level circulation intraseasonal anomalies (Carvalho et al. 2002b, 2004; Jones and Carvalho 2002).

Correlations between LISAM and anomalies (annual mean removed) of GPCP precipitation, and $850 \mathrm{hPa} q, u, v$ and $T$ are shown in Fig. 1. The large scale enhancement of precipitation extending from the intertropical convergence zone (ITCZ) toward southeastern Brazil with maximum signal over the central Amazon characterizes the main precipitation patterns associated with SAMS (Fig. 1a). This pattern is observed along with an enhancement of specific humidity at $850 \mathrm{hPa}$ over most continental SA (Fig. 1b), westerly (easterly) low level winds over central (southern) Brazil (Fig. 1c), northerly low level winds over northern SA (Fig. 1d) and enhancement of low level temperature over eastern Brazil, Atlantic Ocean and subtropics of SA (Fig. 1e). Details on the EOFc analysis including tests of sensitivity for the appropriate set of variables used in this study are thoroughly discussed in Silva and Carvalho (2007).

The second combined EOF (EOFc-2) is independent of LISAM according to the North et al. (1982) criterion and explains about $10 \%$ of the total variance. EOF2c is a yearround pattern. Correlations between EOFc-2 and precipitation, low-level circulation and temperature anomalies (annual mean removed) during the summer (NovemberFebruary) are shown in Fig. 1 and are clearly distinct from the respective patterns obtained with LISAM. For instance,
$\mathrm{EOFc}-2$ shows high positive correlation with precipitation (Fig. 1f) over the southwest tropical Atlantic and negative correlation over southern Brazil and La Plata Basin. High specific humidity in $850 \mathrm{hPa}$ over southeastern Brazil extending toward the Atlantic Ocean (Fig. 1g) is observed along with low-level westerly winds over the same region (Fig. 1h). Northerly (southerly) winds over the northern (southern) flank of maximum precipitation (Fig. 1i) are consistent with the presence of the SACZ (e.g., Kodama 1992). Moreover, negative temperature anomalies (Fig. 1j) are approximately collocated with southerly winds over the southern flank of the SACZ. These features have been previously identified as the seesaw pattern of convective activity and circulation associated with the organization of the SACZ (e.g., Nogues-Paegle and Mo 1997; Liebmann et al. 1999; Herdies et al. 2002; Carvalho et al. 2004). More importantly, EOFc-2 is consistent with previous observations that convection over the southwest South Atlantic typically associated with the SACZ can be decoupled from convective activity over continental SA during summer (Carvalho et al. 2002b, 2004; Muza et al. 2009). EOF2-c time coefficient will be used as an index to identify the oceanic SACZ (Carvalho et al. 2002b, 2004) and will hereafter be referred to as the SACZ index.

Figure 2 shows an example of the time variability of SACZ and LISAM indexes from 2003 to 2007. LISAM shows a clear annual cycle with superimposed high frequency fluctuations. The onset (end) of the rainy season was defined in Silva and Carvalho (2007) when the threepentad (15 days) moving average of LISAM becomes positive (negative). The EOFc-2 time-coefficient, on the other hand, is clearly associated with high frequency variability during all seasons. It is worth emphasizing that the EOFc-2 pattern, here referred to as the oceanic SACZ mode, is not strictly a summer feature, as indicated in Fig. 2. The spatial patterns of correlation obtained between EOFc and above mentioned variables are typical of oceanic cold fronts as indicated in Fig. $1 \mathrm{~g}$ and $\mathrm{j}$ (moisture and temperature, respectively). These synoptic patterns have been previously identified by Kousky (1979) and Kousky and Ferreira (1981) as present both in winter and summer.

Spectral analysis of the SACZ index during the wet season (November-March) indicates a statistically significant peak in the spectrum approximately between 15 and 20 days (not shown), consistent with previous observations (Liebmann et al. 1999; Nogues-Paegle et al. 2000). Extratropical Rossby wave trains are the main forcing for the intraseasonal variability of the SACZ (Casarin and Kousky 1986; Grimm and Silva Dias 1995; Nogues-Paegle and Mo 1997; Liebmann et al. 1999; Jones and Carvalho 2002; Carvalho et al. 2004). Some of these wave trains have been shown to be associated with the eastward propagation of the MJO (Liebmann et al. 2004). LISAM 
Fig. 1 Correlation between LISAM and anomalies (annual mean removed) of precipitation (a), specific humidity (b), zonal wind (c), meridional wind (d), air temperature (e) in $850 \mathrm{hPa}$. Correlations between SACZ and precipitation (f), specific humidity (g), zonal wind (h), meridional wind (i), air temperature (j) in $850 \mathrm{hPa}$
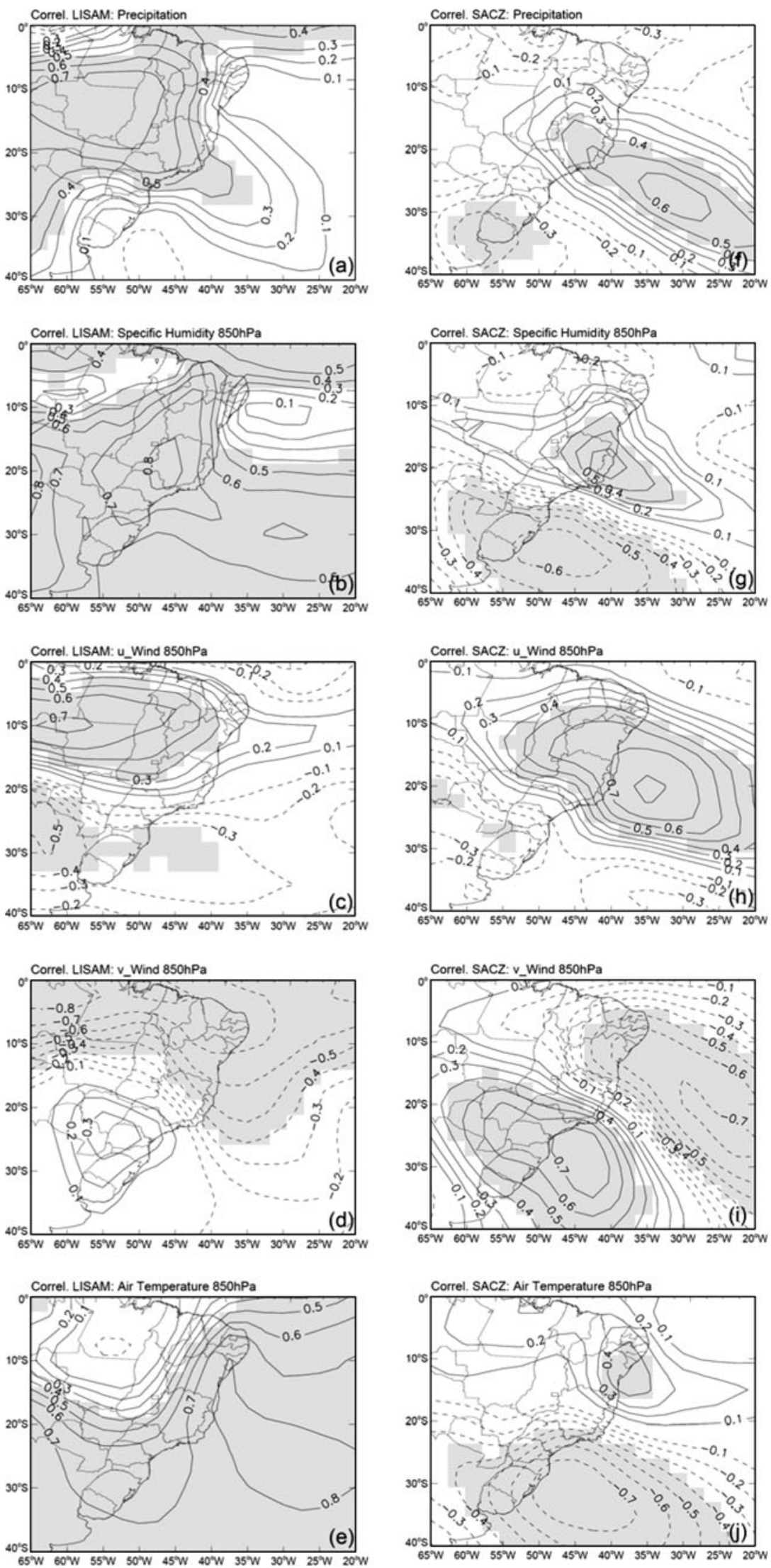
Fig. 2 Example of LISAM and SACZ indexes during 2003-2007

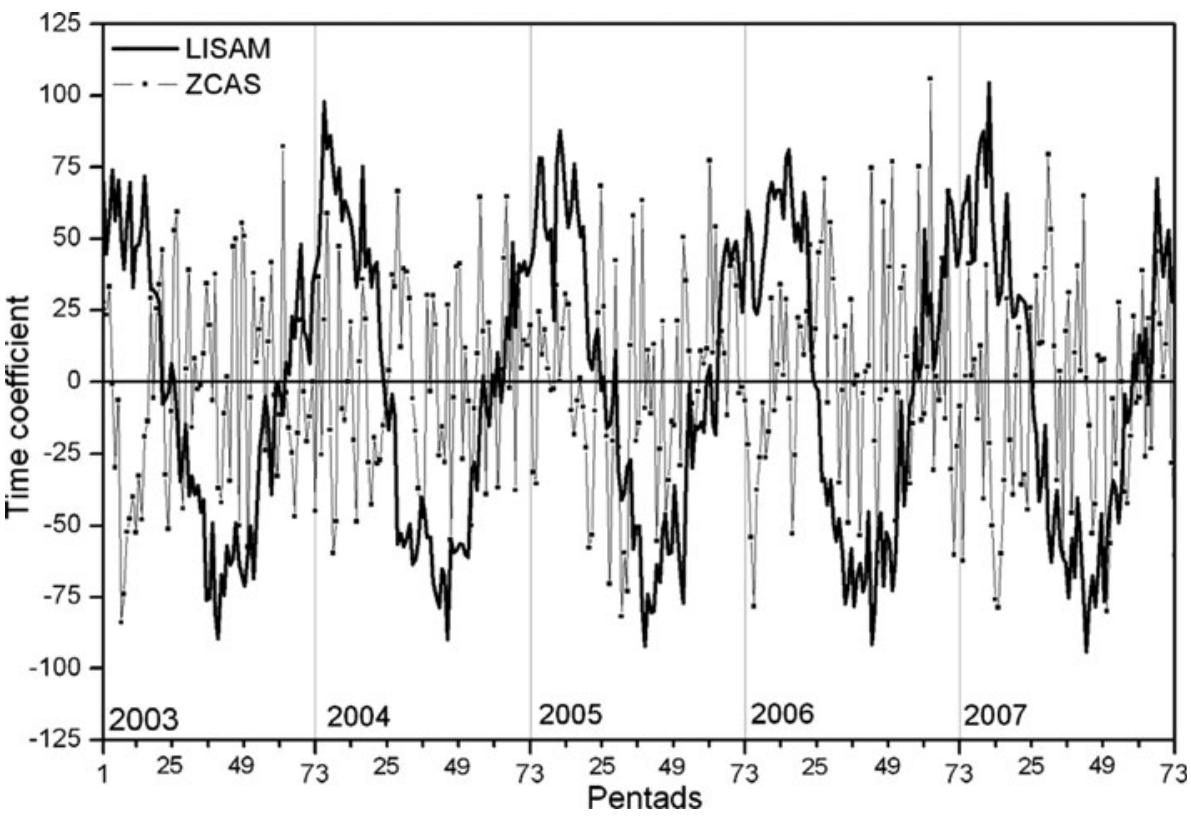

represents large-scale variations of the monsoon over tropical SA and its spectral peak on longer time-scales (3090 days) is consistent with the high variance of Kelvin waves observed in this region during the austral summer (Liebmann et al. 2009).

\section{Continental versus oceanic intraseasonal activity}

The identification of the continental and oceanic variability of convective activity as two distinct modes of SAMS variability is of great relevance for the atmospheric component of the regional hydrological cycle. For instance, previous studies (Carvalho et al. 2002a) have shown that coastal stations over southeastern Brazil are more affected by extreme precipitation during El Niño years than inland stations. Excessive rainfall along the coastal area of Southern and Southeastern Brazil has been associated with low level winds perpendicular to the mountain range that runs parallel to the coast (Xavier and Silva Dias 1995).The proximity to the coast implies therefore in a larger influence of the oceanic activity of the SACZ which can be independent of the rainfall regime over continental areas. Muza et al. (2009) showed that distinct dynamical mechanisms influence the continental and oceanic convective activity associated with the SACZ on interannual timescales.

In this study we objectively separate oceanic from continental convective activity using LISAM and SACZ indexes. Our goal is to understand moisture fluxes during anomalous wet events on intraseasonal time-scales when the monsoon is well established (December-February). For this purpose LISAM and SACZ indexes were both band filtered on intraseasonal timescales (10-100 days) using a band-pass filter in frequency domain. Maximum correlation between the two filtered indexes is observed at zero lag $(\sim 0.24)$ and is not statistically significant at $5 \%$ significance level. No statistically significant correlation was obtained for lags varying from -6 to +6 pentads.

Intraseasonal wet anomalies were then defined when LISAM and SACZ anomalies were above the 75th percentile of the distribution of the respective anomalies (hereafter referred to as $\mathrm{LISAM}_{\mathrm{IS}}$ and $\mathrm{SACZ}_{\mathrm{IS}}$ ). Although the two indexes are uncorrelated in time, there are some events during which LISAM $_{\text {IS }}$ and SACZ $_{\text {IS }}$ simultaneously satisfy the wet event criterion. These events are potentially relevant as they indicate a simultaneous enhancement of convection over southeastern SA and the subtropical Atlantic Ocean. We examined separately all LISAM ${ }_{I S}$ and $\mathrm{SACZ}_{\mathrm{IS}}$ events that were not coincident, that is they did not simultaneously satisfy the wet LISAM $_{I S}$ and wet SACZ $_{\text {IS }}$ criteria. Likewise, we also investigate those events during which LISAM $_{\text {IS }}$ and SACZ $_{\text {IS }}$ simultaneously satisfied the wet criteria for at least one pentad (henceforth referred to as LISAM $_{I S}+$ SACZ IS $_{\text {IS }}$ events).

Thirty LISAM $_{I S}$, thirty nine $\mathrm{SACZ}_{\mathrm{IS}}$ and thirty eight LISAM $_{I S}+$ SACZ $_{I S}$ independent events were examined in this study during DJF of the 1979/1980-2006/2007 monsoon seasons. Independent events are considered as events that are at least two pentads apart. Figure 3 shows composites of outgoing longwave radiation (OLR) intraseasonal anomalies (10-100 days) for LISAM $\mathrm{IS}_{\mathrm{IS}}, \mathrm{SACZ}_{\mathrm{IS}}$ and LISAM IS $_{\text {IS }}$ SACZ $_{\text {IS }}$ events. OLR anomalies were used in this analysis as an independent proxy for convective 
Fig. 3 OLR Intraseasonal anomalies (10-90 days) for $\operatorname{LISAM}_{\mathrm{IS}}(\mathbf{a}) \mathrm{SACZ}_{\mathrm{IS}}(\mathbf{b})$ and LISAM IS + SACZ IS $_{\text {(c) }}$
LISAM (wet): OLR

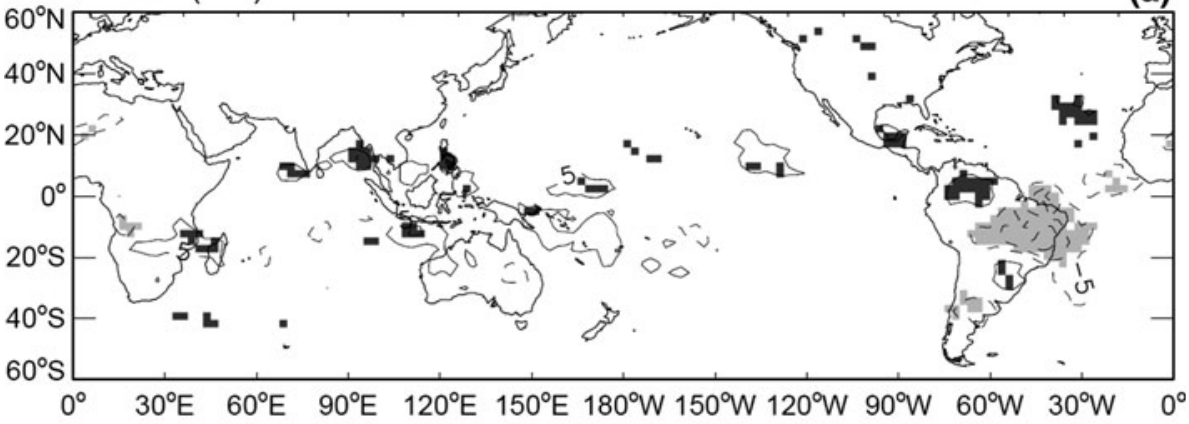

SACZ (wet): OLR

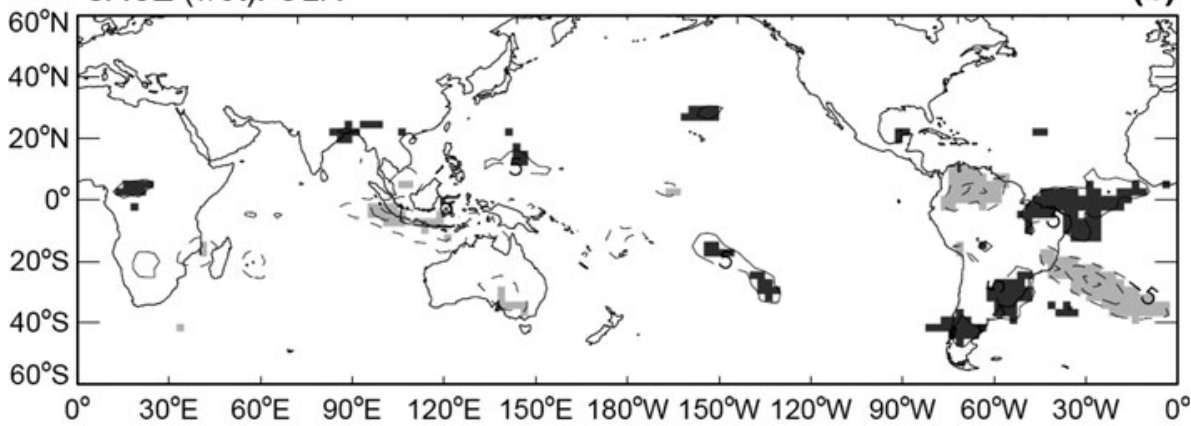

Coincident (wet): OLR

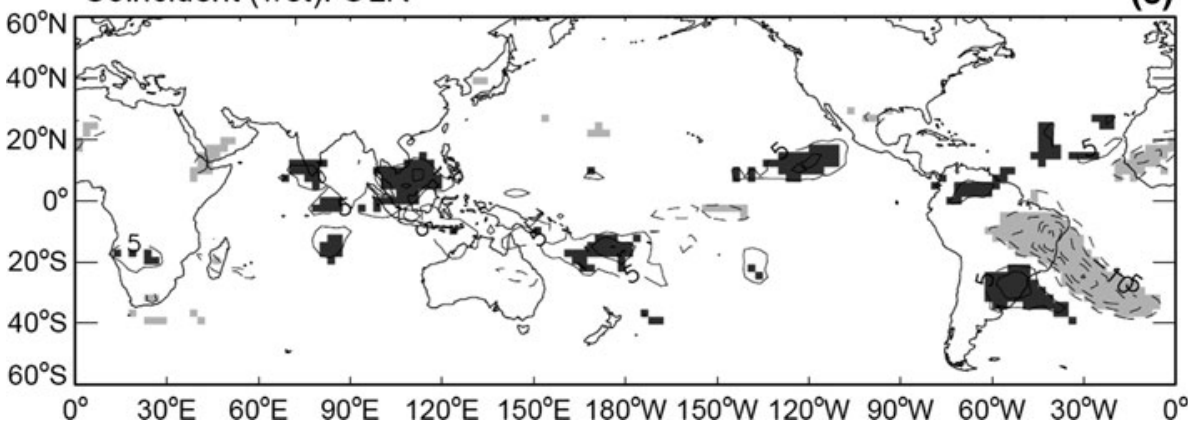

activity that was not used in the definition of LISAM and SACZ indexes. Composites are shown only for lag 0 . They clearly indicate that LISAM $_{\text {IS }}$ events are associated with intense convective activity over tropical central-eastern Brazil and suppression over northern SA (Fig. 3a). The existence of a dipole in the convective activity on intraseasonal time-scales between northern and central Amazon has been previously identified in (Carvalho et al. 2002a). In contrast, $\mathrm{SACZ}_{\mathrm{IS}}$ wet events (Fig. 3b) are associated with convective activity displaced toward the Atlantic Ocean along with suppression of convection over southern Brazil, Uruguay, southern Argentina, and in the ITCZ region, which indicates association with wave trains. There is also indication of enhancement of convective activity over northwestern SA during these events (Fig. 3b). LISAM $_{I S}+$ SACZ $_{\text {IS }}$ events (Fig. 3c) clearly indicate the combined enhancement of convection over the continent with extension toward the subtropical Atlantic Ocean associated with simultaneous wet LISAM $_{\text {IS }}$ and SACZ $_{\text {IS }}$ anomalies. Suppression of convective activity is observed over southern Brazil, Uruguay and northeastern Argentina, which characterize the seesaw in convective anomalies on intraseasonal time scale that has been extensively documented in previous papers (Nogues-Paegle and Mo 1997; Liebmann et al. 1999; Carvalho et al. 2004). Lag-composites of OLR intraseasonal anomalies do not clearly indicate coherent patterns of convection over the tropical and equatorial Pacific that resemble the canonical propagation of $\mathrm{MJO}$ and its remote influence on SA, as suggested in previous studies (Carvalho et al. 2004; Jones et al. 2004a). It is important to note, however, that there is a large case-to-case variability in the convective activity related to the propagation of the MJO (Wang and Rui 1990; Jones et al. 2004b) and links with the oscillation based on composites of OLR intraseasonal anomalies can be misleading. 
Figure 4 shows the interannual distribution of wet

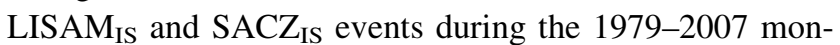
soon seasons. At least one $\mathrm{LISAM}_{\mathrm{IS}}$ and/or SACZ $\mathrm{IS}$ wet event occurred every season, with exception of the 1981/ 1982, 1982/1983, 1989/1990 and 2006/2007 DJF seasons. $\mathrm{LISAM}_{\mathrm{IS}}+\mathrm{SACZ}_{\mathrm{IS}}$ events dominate the wet events during these years. In the 1979/1980-1988/1989 decade the

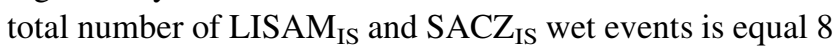
and 10, respectively. In the 1990/1991-1999/2000 decade the number of LISAM ${ }_{I S}$ and SACZ IS wet events approximately doubled to 17 and 19 events, respectively. No significant differences are observed for LISAM $_{\text {IS }}+$ SACZ IS $_{\text {IS }}$ events, which varied from 15 in the 1979-1989 decade to 11 in the 1990-2000 decade. The total number of wet events classified in Fig. 4 is equal 33 in the 1979-1989 decade against 47 in the 1990-2000 decade, which represents an increase of $42 \%$ in the latter period. Jones and Carvalho $(2006,2009)$ have shown evidence of decadal variability in the number of MJO events with the 1990s more active than the 1980 s.

\section{Moisture transport and intraseasonal activity}

The propagation of tropical and extratropical intraseasonal disturbances causes significant changes in regional atmospheric circulations (Jones and Carvalho 2002; Carvalho et al 2002a; Liebmann et al. 2004) and in moisture transport (Herdies et al. 2002) over SA that can persist from one up to five pentads (Muza et al. 2009). The objective of the present study is to evaluate the transport of when convection increases over central SA during active phases of the monsoon with no evident organization of the SACZ over the ocean (LISAM IS events). Likewise, we will investigate how moisture transport changes when the SACZ is active along with weak convective activity over the continent $\left(\mathrm{SACZ}_{\mathrm{IS}}\right.$ events) and when convection over southeastern

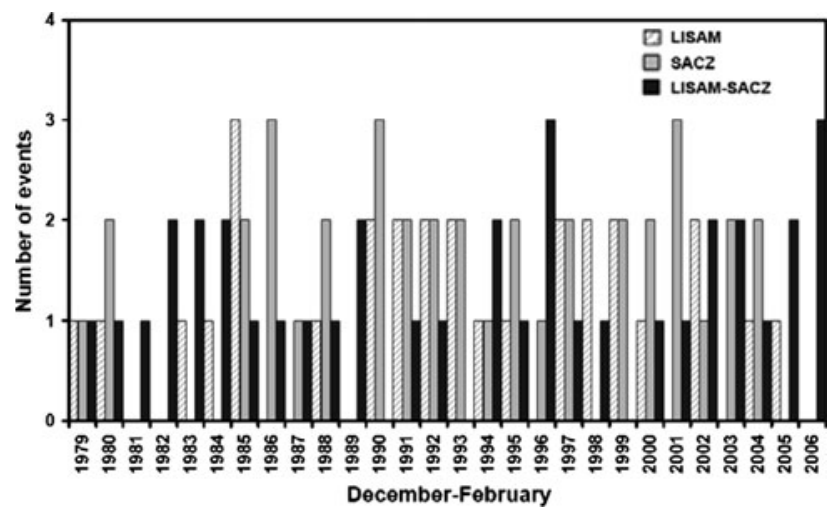

Fig. 4 Interannual variability in the number of LISAM ${ }_{I S}, S A C Z_{I S}$ and LISAM $_{I S}+$ SACZ $_{\text {IS }}$ wet events
SA and southwestern Atlantic is very intense (LISAM IS $_{+}$ $\mathrm{SACZ}_{\mathrm{IS}}$ events). The spatial resolution of the grid cells considered in this study is $2.5^{\circ} \times 2.5^{\circ}$ latitude/longitude ( $\sim 10^{5} \mathrm{~km}^{2}$ in the tropics).

The vertically integrated moisture flux $\left(\mathrm{kg} \mathrm{m}^{-1}\right.$ day $\left.^{-1}\right)$ was decomposed into zonal $f u$ and meridional $f v$ components according to Peixoto and Oort (1992) based on the following approach:

$f u=\frac{1}{g} \int_{n+1}^{n} q u d p=\frac{1}{g} \sum_{n=1}^{N} \frac{\left[(u q)_{n+1}+(u q)_{n}\right]}{2}\left[p_{n}-p_{n+1}\right]$

$f v=\frac{1}{g} \int_{n+1}^{n} q v d p=\frac{1}{g} \sum_{n=1}^{N} \frac{\left[(q v)_{n+1}+(q v)_{n}\right]}{2}\left[p_{n}-p_{n+1}\right]$

where $q$ is the specific humidity $\left(\mathrm{kg} \mathrm{kg}^{-1}\right), \mathrm{u}$ and $\mathrm{v}$ are the wind zonal and meridional components, respectively $\left(\mathrm{m} \mathrm{s}^{-1}\right)$. The integral is calculated from pressure $p$ at surface up to $300-\mathrm{hPa}$.

In this study we examine variations in the moisture transport associated with LISAM $_{I S}, \mathrm{SACZ}_{\mathrm{IS}}$ and LISAM $_{\text {IS }}+$ SACZ $_{\text {IS }}$ wet events. Moisture transport will be examined by computing the zonal (Eq. 1) and meridional (Eq. 2) components of the integrated moisture flux during the DJF seasons. Anomalies with respect to the climatology were computed for both components separately and then summed. The description of the dynamical systems observed during the events will be addressed by lag-composites of streamfunction anomalies.

\subsection{LISAM $_{\text {IS }}$ wet events}

Lag composites of vertically integrated moisture flux

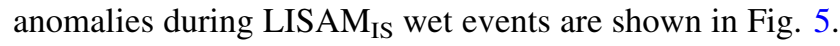
About one pentad before the occurrence of LISAM LS $_{\text {IS }}$ events the anomalous integrated moisture flux indicates the amplification of a trough in the Northern Hemisphere over the subtropical Pacific near the west coast of North America (Fig. 5a). This trough transports moisture from the tropics and subtropics of the western Pacific toward California. The wave like pattern is also evident from midwestern to southeastern North America and the Caribbean and indicates an increase in the equatorward transport of humidity in this region. Northerly moisture transport is observed over northern SA at the same lag. There is also indication of wave activity in the extratropics and subtropics of the Southern Hemisphere as well, which increases the easterly contribution of the vertically integrated moisture flux over southeastern Brazil. Concomitantly with LISAM $_{\text {IS }}$ wet events (Fig. 5b) there is an intensification of the northwesterly moisture flux across the equator toward tropical SA. Moisture fluxes are larger over 
Fig. 5 LISAM $_{\text {IS lag- }}$ composites of the integrated moisture flux
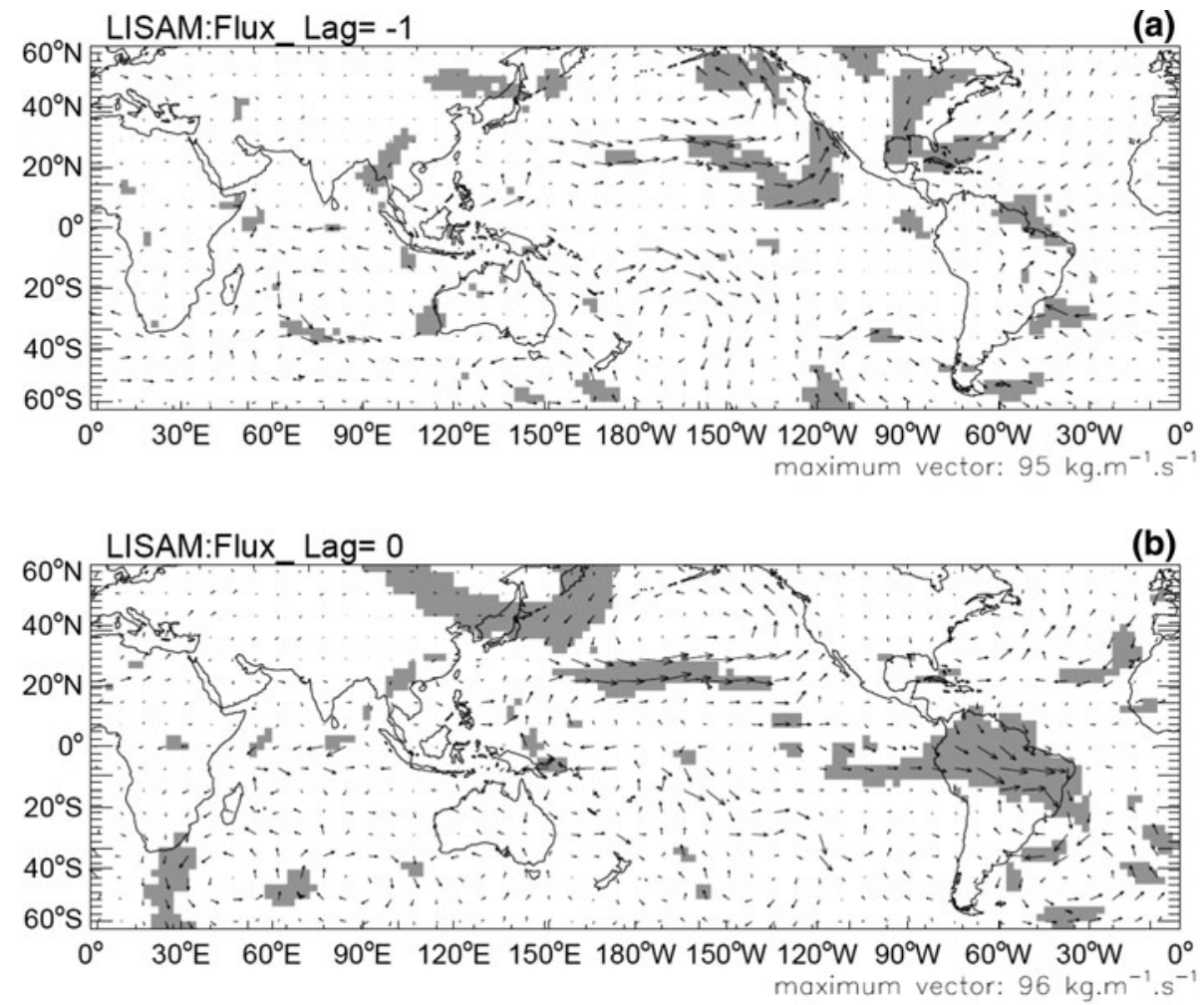

LISAM:Flux_Lag $=1$

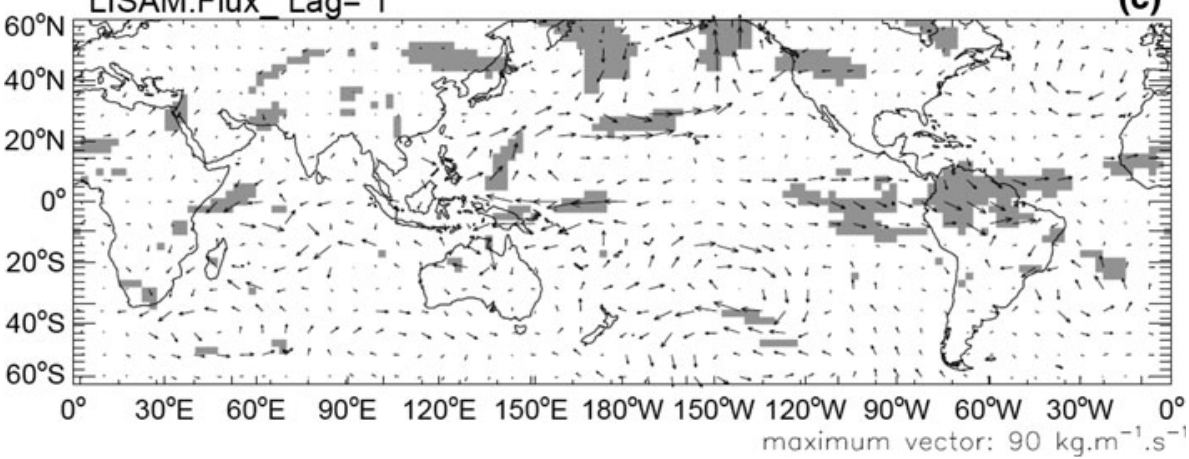

central-eastern SA. One pentad later (Fig. 5c) low level northwesterly anomalies near equatorial SA still persist (not shown) and maintain the westerly moisture fluxes over northeastern SA approximately between $10^{\circ} \mathrm{S}$ and $10^{\circ} \mathrm{N}$.

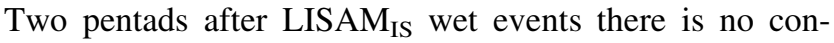
sistent anomaly of moisture fluxes over SA (not shown).

Rossby waves propagating into the tropics have been identified in association with westerly flow that extends from the extratropics into low latitudes (Kasahara and Silva Dias 1986; Hsu and Lin 1992; Kiladis and Weickmann 1992a, b; Tomas and Webster 1994). Strong westerly jets such as the Asian and the Southern Hemisphere jets can act as Rossby waveguides with wave paths arching across North America and SA (Hoskins and Ambrizzi 1993). These westerly jets have a fundamental role in the energy conversion from the baroclinic perturbations driven by latent heat release in the tropics into barotropic anomalies that characterize the teleconnection patterns (Kasahara and Silva Dias 1986).

Rossby wave activity in both hemispheres in association with LISAM $\mathrm{IS}_{\mathrm{IS}}$ wet events can be observed from lag composites of 200-hPa streamfunction anomalies (Fig. 6). Notice that no filtering was applied to these fields in order to keep most of the high frequency variability of the midlatitude Rossby waves (Kiladis and Weickmann 1992a, b). A well characterized wave-like pattern in $200 \mathrm{hPa}$ streamfunction anomalies is observed extending from the Equator toward high latitudes of Northern Hemisphere one pentad preceding LISAM $_{\text {IS }}$ wet events (Fig. 6a). This feature follows the Pacific-Atlantic wave path shown in Hoskins and Ambrizzi (1993) and resembles the Pacific North American (PNA) teleconnection pattern (Wallace 
Fig. $6200 \mathrm{hPa}$ streamfunction anomalies (climatology removed) during LISAM $_{\mathrm{IS}}$ wet events
LISAM: PSI 200hPa $\left(\times 10^{6} \mathrm{~m}^{2} \cdot \mathrm{s}^{-1}\right)_{-} \mathrm{Lag}=-1$

(a)

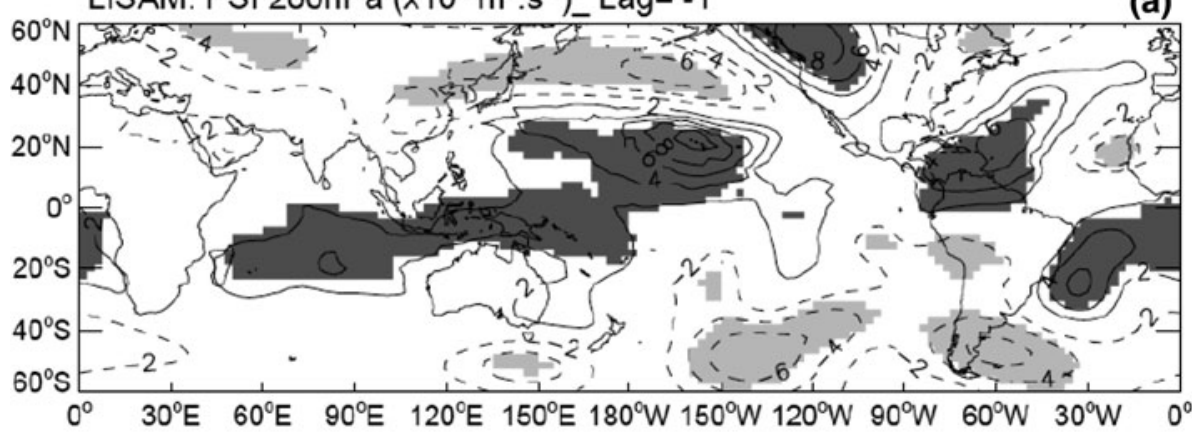

LISAM: PSI $200 \mathrm{hPa}\left(\times 10^{6} \mathrm{~m}^{2} . \mathrm{s}^{-1}\right) \_\mathrm{Lag}=0$

(b)

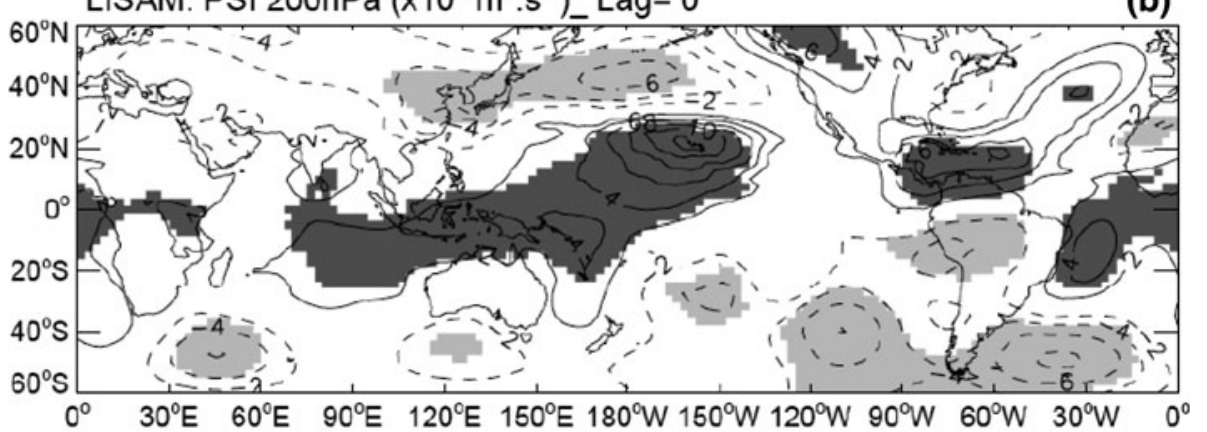

LISAM: PSI $200 \mathrm{hPa}\left(\times 10^{6} \mathrm{~m}^{2} . \mathrm{s}^{-1}\right)_{-} \mathrm{Lag}=1$

(c)

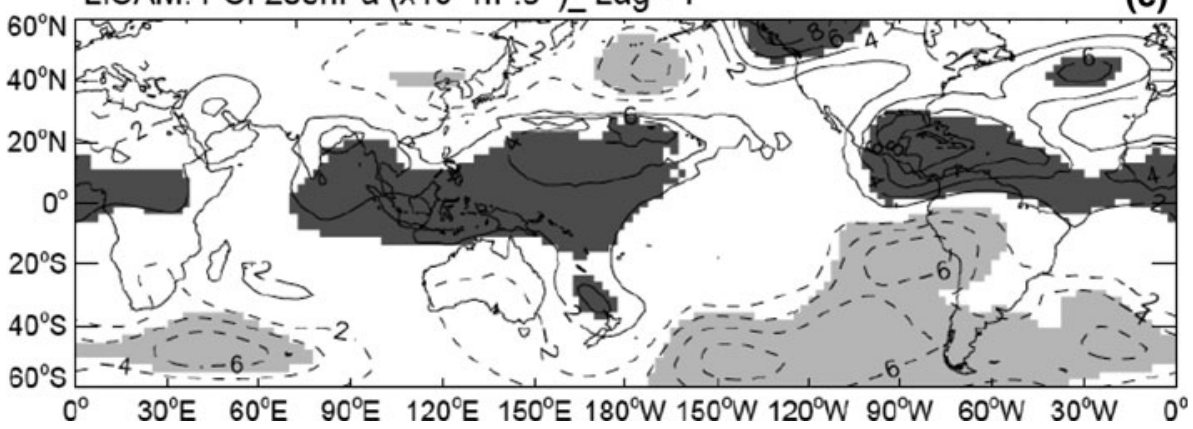

and Gutzler 1981) in its positive phase. The PNA pattern is coupled to fluctuations in the strength and location of the Asian-jet stream and to anomalous convection in the equatorial Pacific (Grimm and Silva Dias 1995). The positive phase of the PNA indicates an enhancement of the East Asian jet stream and an eastward shift in the jet exit region toward the western United States and increased upward motion over the Central Equatorial Pacific and midtropospheric subsidence in the region of the upper westerly jet.

The positive phase of the PNA is related to the anomalous vertically integrated moisture transport by the two pair of troughs over western and eastern North America (Fig. 5a). In the Southern Hemisphere there is indication of an intensification of the upper cyclonic vortex off the Northeast coast of Brazil, known as the Northeast trough (Lenters and Cook 1997; Gandu and Silva Dias 1998) along with a pair of anti-cyclones in mid latitudes (Fig. 6a).
The latter are related to the weakening of the subtropical jet near the southern coast of Brazil and La Plata basin (not shown).

Concomitantly with LISAM $_{\text {IS }}$ wet events the PNA remains in its positive phase and seems to intensify over the tropical Pacific and Atlantic (Fig. 6b). Concurrently, low level westerly anomalies are observed near the equator (not shown) along with a cross equatorial transport of moisture, intensification of moisture fluxes over central Brazil (Fig. 5b) and enhanced convection in the same region (Fig. 3a). Early studies have shown that cross equatorial dispersion of wave energy from the extratropics of the Northern Hemisphere toward the Southern Hemisphere increases with the magnitude of the westerlies over the equator (e.g., Webster and Holton 1982). The Southern Hemisphere connection with the PNA has been attributed to the anomalous heat source in the equatorial Pacific (Grimm and Silva Dias 1995). The anomalous heat source 
in the central and western Equatorial Pacific triggers Kelvin waves that generate strong upper level westerly flow anomalies in the eastern Pacific. In this study, the cross-equatorial anomalous flux is not clearly observed in association with convective activity along the Equatorial Pacific from OLR anomalies, possibly due to large case-tocase variability. The intensification of moisture fluxes north of the Equator one pentad before LISAM IS $_{\text {wet (Fig. 6a) }}$ seems to contribute to the intensification of convective activity near Equatorial South America. Convectively coupled Kelvin waves have non negligible meridional component in regions of deep convection (Straub and Kiladis 2002; Dias and Pauluis 2009). The upper tropospheric Kelvin wave, with the associated baroclinic structure, is revealed in the intensification of the zonal moisture flow in the equatorial portion of the South American continent (Fig. 5b).

As convection intensifies over the Amazon and central Brazil, the Bolivian high becomes well established (Silva Dias et al. 1983) along with the Northeast trough (Gandu and Silva Dias 1998). Westerly wind anomalies in $200 \mathrm{hPa}$ intensify near the Equator off the west coast of SA toward central eastern SA where most of the convective activity takes place (not shown). One pentad after the LISAM IS wet events the PNA pattern over north Pacific and the East-Asian jet weaken, although the PNA remains in its positive phase (Fig. 6c). The weakening of the PNA is observed along with the decrease in the vertically integrated moisture flux across northern SA (Fig. 5c). Meanwhile, the Northeast trough weakens and upper level positive vorticity dominates in the midlatitudes of the Southern Hemisphere. These combined features characterize the weakening of LISAM $_{\mathrm{IS}}$ wet events.

\section{2 $\mathrm{SACZ}_{\mathrm{IS}}$ wet events}

Lag composites of the anomalies of the vertically integrated moisture flux during $\mathrm{SACZ}_{\mathrm{IS}}$ wet events are shown in Fig. 7. One pentad before the events (Fig. 7a) there is evidence of a wave train in the extratropics of the Southern Hemisphere that is transporting moisture from midlatitudes toward southern Argentina. No statistically significant anomalies are observed in the Northern Hemisphere prior and during the event. For lag 0 (Fig. 7b) the easterly moisture transport from subtropical Atlantic intensifies as the wave train moves northward. Easterly anomalies in moisture transport are observed over southeastern South America at the southern flank of the SACZ. Northwesterly anomalies are observed co-located with and at the northern flank of the oceanic SACZ (compare with Fig. 3b). One pentad after the event, anomalous convection weakens over the ocean and the SACZ is no longer evident (not shown). The weakening of the SACZ is observed along with the intensification of the easterly moisture transport over northwest SA (Fig. 7c).

Rossby wave activity in the Southern Hemisphere during $\mathrm{SACZ}_{\mathrm{IS}}$ wet events can be identified from lag composites of anomalous streamfunction at $200 \mathrm{hPa}$ (Fig. 8). For consistency with previous analysis (Fig. 6) only the annual cycle was removed and no further filtering was applied. One pentad before $\mathrm{SACZ}_{\mathrm{IS}}$ wet events (Fig. 8a) a wave like pattern extending from Indonesia toward high latitudes of the Southern Hemisphere becomes evident and resembles the Pacific South American (PSA) teleconnection pattern (Grimm and Silva Dias 1995; Mo and Paegle 2001). The existence of a wave number- 3 pattern becomes much more evident in composites of 10-100 day bandfiltered streamfunction anomalies (not shown). Another region with anti-cyclonic circulation is observed in the subtropics of the Northern Hemisphere over central Pacific but there is no evidence of the PNA pattern, as observed during LISAM $_{\text {IS }}$ wet events (compare with Fig. 6a). No statistically significant anomaly in the zonal winds in $200 \mathrm{hPa}$ in association with Asian subtropical Jet is observed one pentad prior, during or after the event. This is a consequence of the connection between the Southern Hemisphere wave train and the anomalous convection in the SPCZ region that more strongly interacts with the Southern Hemisphere summer teleconnection patterns (Grimm and Silva Dias 1995). The PSA becomes well characterized in high latitudes of the Southern Hemisphere for lag 0 (Fig. 8b), consistent with the intensification of the SACZ over the ocean (Fig. 3b). One pentad later the PSA pattern weakens in the subtropics and extratropics of the Southern Hemisphere and enhanced convection in the SACZ is no longer evident (not shown).

\subsection{LISAM $_{\mathrm{IS}}+\mathrm{SACZ}_{\mathrm{IS}}$ wet events}

Lag composites during LISAM $_{\mathrm{IS}}+\mathrm{SACZ}_{\mathrm{IS}}$ wet events were obtained by averaging only pentads when both indexes satisfied the criterion of wet events discussed before. It is possible, however, that in some cases $\mathrm{SACZ}_{\mathrm{IS}}$ or LISAM $_{\mathrm{IS}}$ alone satisfied the criterion for a wet event longer than the period when both indexes were above the 75th percentile. Those pentads were not included in the composites. The vertically integrated moisture flux is shown in Fig. 9. These events combine features discussed previously for LISAM IS and SACZ IS wet events and are associated with the largest magnitude of the vertically integrated moisture transport anomalies over the tropics. One pentad before the event (Fig. 9a) westerly anomalous moisture transport is observed at the subtropics of the Northern Hemisphere over central Pacific and Atlantic. These anomalies indicate the enhancement of zonal winds in the lower and mid troposphere at these latitudes. 
Fig. 7 The same as Fig. 5 but for the $\mathrm{SACZ}_{\mathrm{IS}}$

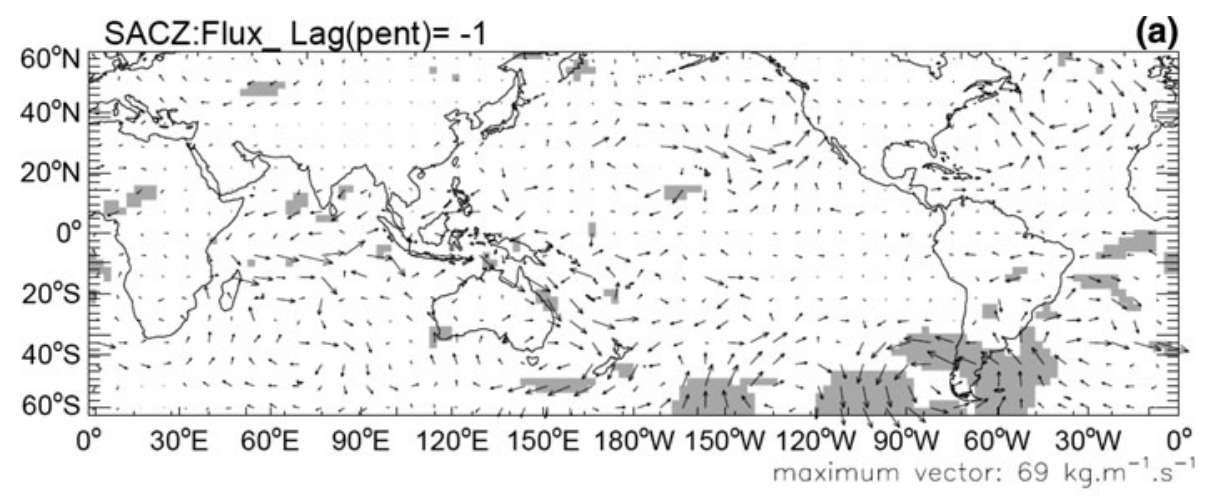

SACZ:Flux_Lag(pent) $=0$

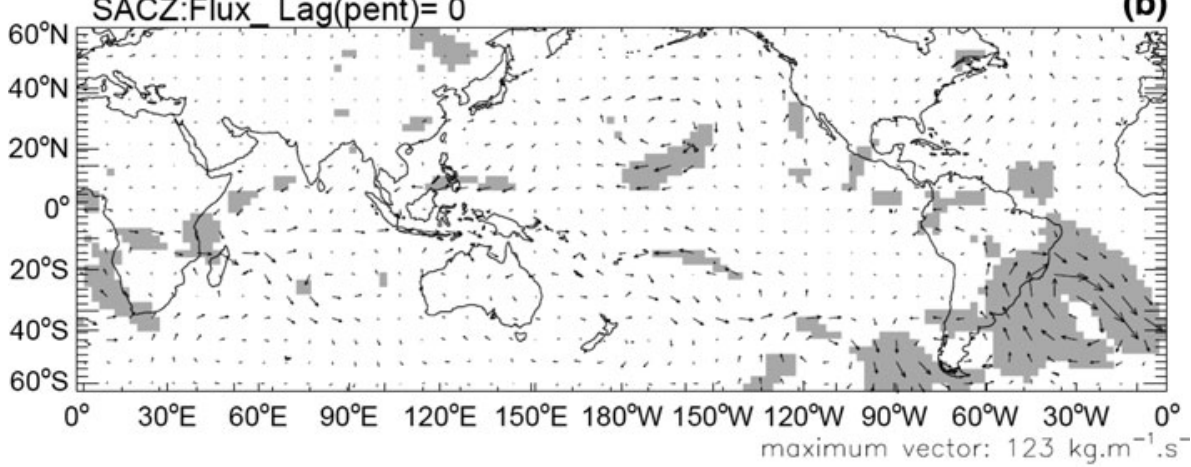

SACZ:Flux Lag(pent) $=1$

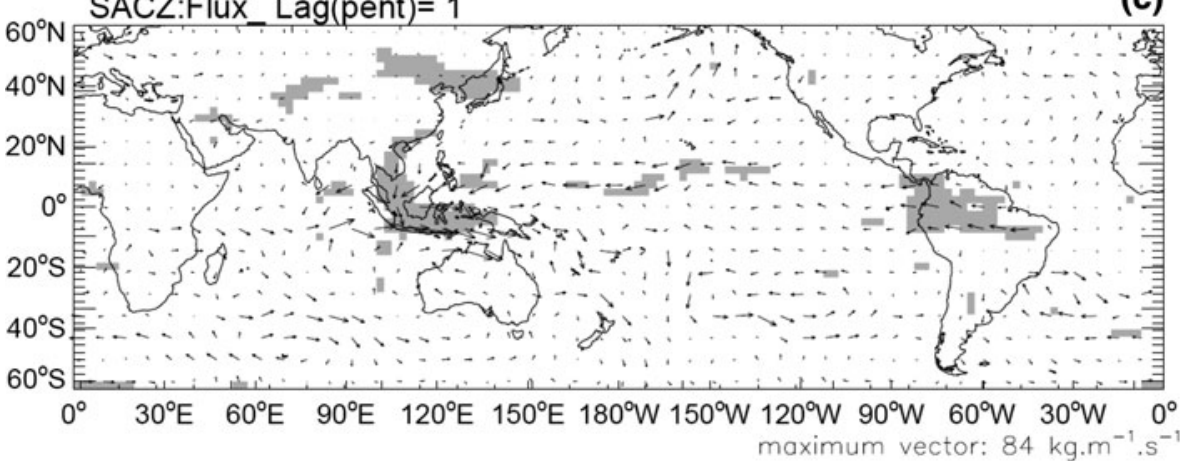

Westerly moisture transport increases in the Southern Hemisphere over tropical Pacific near the date line. There is also evidence of wave activity in the Southern Hemisphere indicated by the anomalous cyclonic transport in the extratropics and subtropics of South America. For lag 0 the anomalous cyclonic transport with center over subtropical western Atlantic intensifies over the continent and the ocean (Fig. 9b). There is indication of cross-equatorial anomalous northwesterly transport of moisture extending from the Amazon toward tropical Atlantic (Fig. 9b). In the Northern Hemisphere, anomalous cyclonic moisture flux over central subtropical Pacific persists for lag 0. One pentad after the event (Fig. 9c), westerly anomalies are observed over tropical South America and Equatorial Pacific off the west coast of the continent and along the
Atlantic ITCZ (Fig. 9c). The anomalous cyclonic moisture transport over subtropical Atlantic weakens whereas the anomalous cyclonic moisture transport over subtropical North Pacific intensifies (Fig. 9c).

Figure 10 shows lag composites of the streamfunction anomalies during LISAM $_{I S}+$ SACZ $_{I S}$ wet events. One pentad before the event (Fig. 10a), negative streamfunction anomalies in high latitudes of the Northern Pacific and positive over Tropical Pacific near the date line indicates the enhancement of the boreal winter subtropical Asian jet. Nevertheless, the PNA is not clearly observed as a wave number-3 pattern from the tropics to the extratropics of the Northern Hemisphere. The pair of cyclonic anomalies off the west coast of North America and over eastern extratropical North America and North Atlantic characterizes a 
Fig. 8 The same as Fig. 6 but for $\mathrm{SACZ}_{\mathrm{IS}}$ wet events
SACZ: PSI 200hPa $\left(\times 10^{6} \mathrm{~m}^{2} \cdot \mathrm{s}^{-1}\right)_{-} \mathrm{Lag}=-1$

(a)

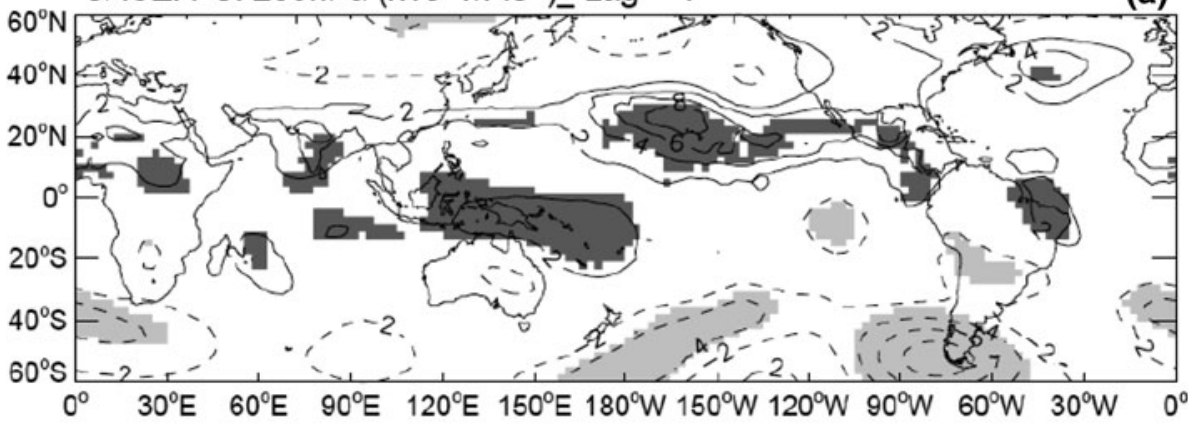

SACZ: PSI 200hPa $\left(x 10^{6} \mathrm{~m}^{2} \cdot \mathrm{s}^{-1}\right) \quad$ Lag $=0$

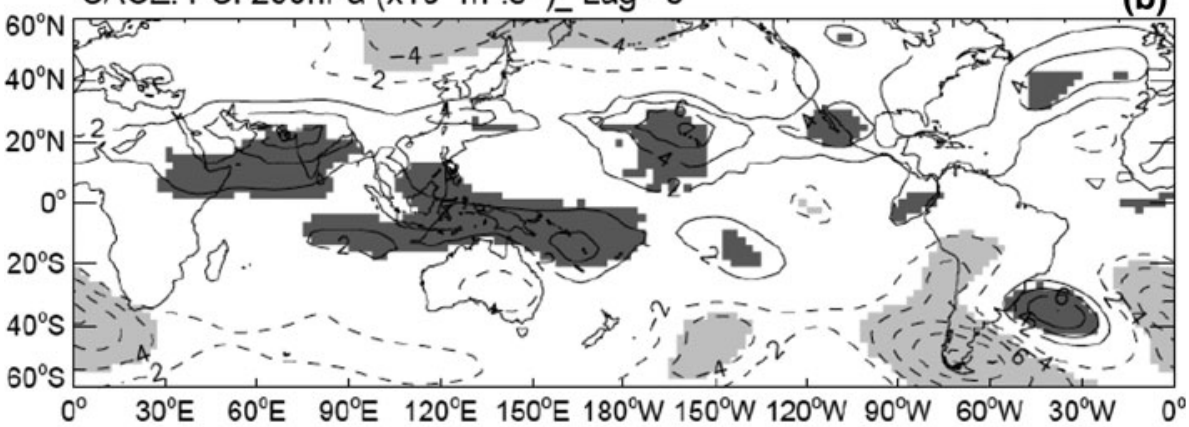

SACZ: PSI $200 \mathrm{hPa}\left(\times 10^{6} \mathrm{~m}^{2} \cdot \mathrm{s}^{-1}\right)_{-} \mathrm{Lag}=1$

(c)

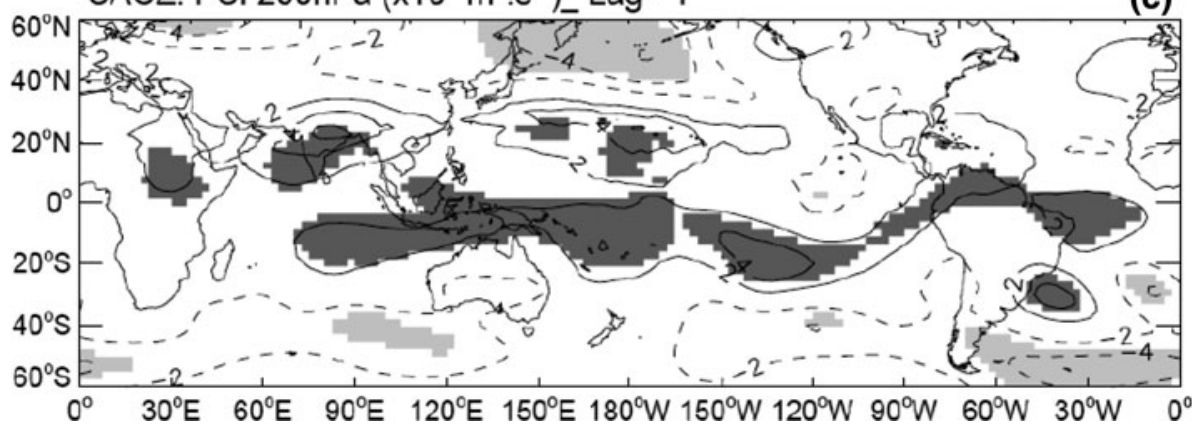

wave number- 1 pattern in the streamfunction anomalies in midlatitudes of the Northern Hemisphere. In the Southern Hemisphere, however, the PSA becomes evident (Fig. 10a) as a wave-3 pattern from Indonesia toward midlatitudes. The Northeast trough is very pronounced one pentad prior the event as part of the wave- 1 tropical cyclonic anomaly observed in low latitudes of the southern Hemisphere (Fig. 10a). For lag 0 (Fig. 10b), a midlatitude wave train that arches around SA intensifies in the extratropics and subtropics which explains the enhancement of moisture fluxes from the subtropical Atlantic Ocean observed simultaneously with the event (Fig. 9b). The inter-hemispheric transport of moisture indicated in Fig. $9 \mathrm{~b}$ is consistent with positive streamfunction anomalies north of the Equator over the Caribbean and north of South America (Fig. 10b). One pentad after the event (Fig. 10c), the wave pattern over eastern SA weakens which is consistent with the weakening of the $\mathrm{LISAM}_{\mathrm{IS}}+\mathrm{SACZ}_{\mathrm{IS}}$ wet events.

\section{Conclusions}

This study proposes a new approach to investigate the large-scale variability of SAMS by performing a combined EOF of precipitation, temperature, moisture and circulation anomalies (annual mean removed) over tropical and subtropical South America. The first combined EOF (LISAM) characterizes the monsoon as a seasonal reversal in precipitation and circulation anomalies over central South America. The second combined EOF distinguishes the oceanic activity that affects Southeastern Brazil with opposite signal over southern Brazil, Uruguay and northeastern Argentina that has been associated with the SACZ. The advantage of this approach is that it allows characterizing the main large-scale features of SAMS without restricting our analysis to boxes or any arbitrary region. Moreover, multiple datasets such as NCEP/NCAR reanalysis and GPCP pentad precipitation are employed in this 
Fig. 9 The same as Fig. 5 but for $\mathrm{LISAM}_{\mathrm{IS}}+\mathrm{SACZ}_{\mathrm{IS}}$ wet events

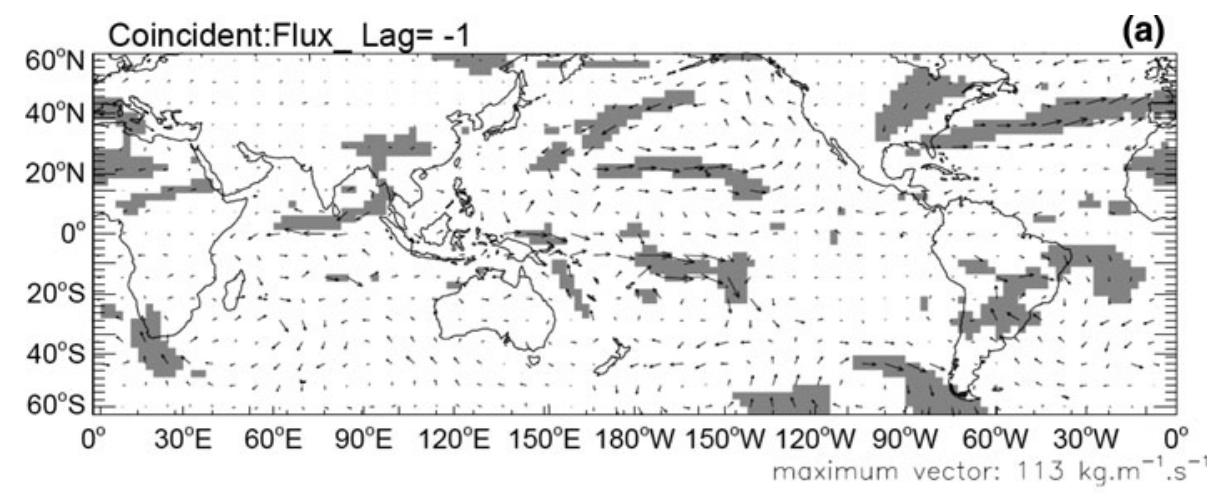

Coincident:Flux Lag $=0$

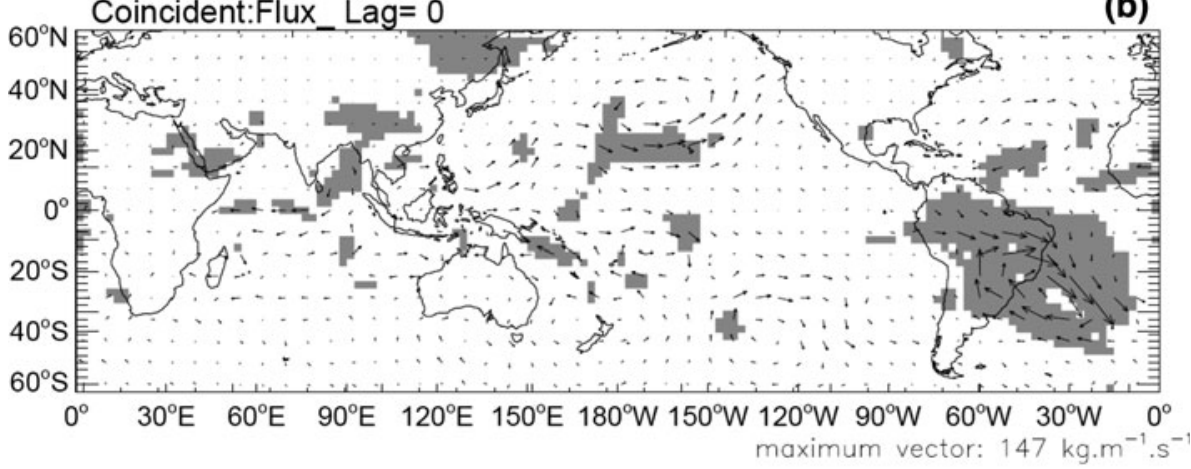

Coincident:Flux_Lag= 1

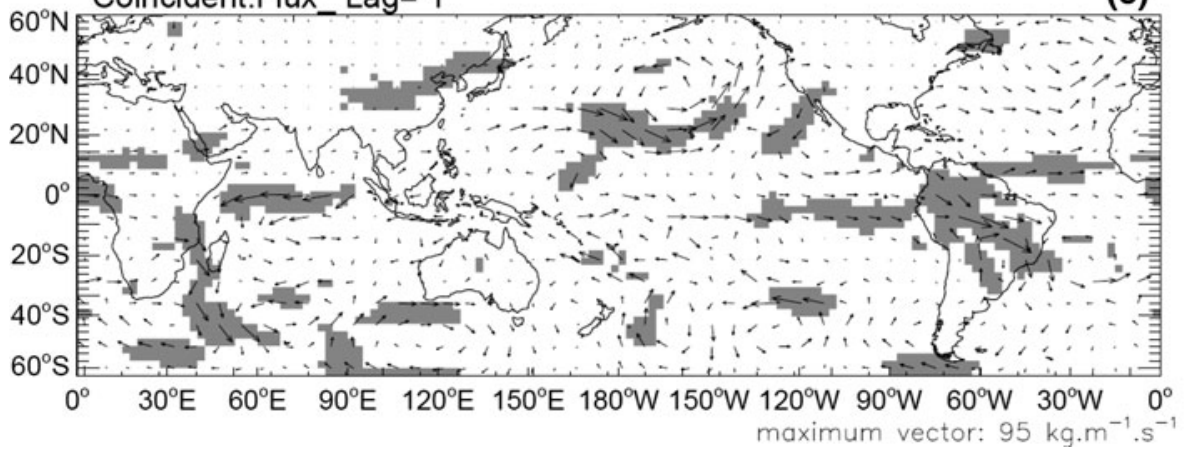

analysis. Our objective in using the latter was to extend our analysis to the Atlantic Ocean and therefore to characterize the variability of the SACZ. The disadvantage of using pentad data is to smooth out variations on synoptic scales (period less than 10 days) which might account for large variance of the spectrum in the monsoon region particularly upon the SACZ. Nevertheless, LISAM and SACZ indexes show spectral variance on intraseasonal timescales that have been extensively documented in previous studies (e.g. Liebmann et al. 1999, 2009; Nogues-Paegle and Mo 1997; Muza et al. 2009). These properties were further used to investigate moisture transport during wet events on intraseasonal timescales.

Enhanced amplitudes of SAMS continental activity on intraseasonal timescales as determined with LISAM are associated with cross-equatorial northwesterly moisture flux anomalies over the Amazon and central Brazil. Crossequatorial flow over western Amazon has been related to seasonal variations in precipitation over South America (Wang and $\mathrm{Fu}$ 2002). Here we show that similar mechanism drives variations on shorter timescales and are associated with the strengthening of the Asian subtropical jet and the PNA in its positive phase. These findings clearly indicate that the cross-equatorial flux plays an important role for changes in moisture fluxes that ultimately enhance convection over central-eastern Brazil on intraseasonal timescales. Those events represent an increase in the contribution to the monsoon precipitation from moisture transported from northern Amazon toward eastern South America

In contrast, enhanced amplitudes of convective activity on intraseasonal timescales identified by the SACZ index 
Fig. 10 The same as Fig. 6 but for $\mathrm{LISAM}_{\mathrm{IS}}+\mathrm{SACZ}_{\mathrm{IS}}$ wet events

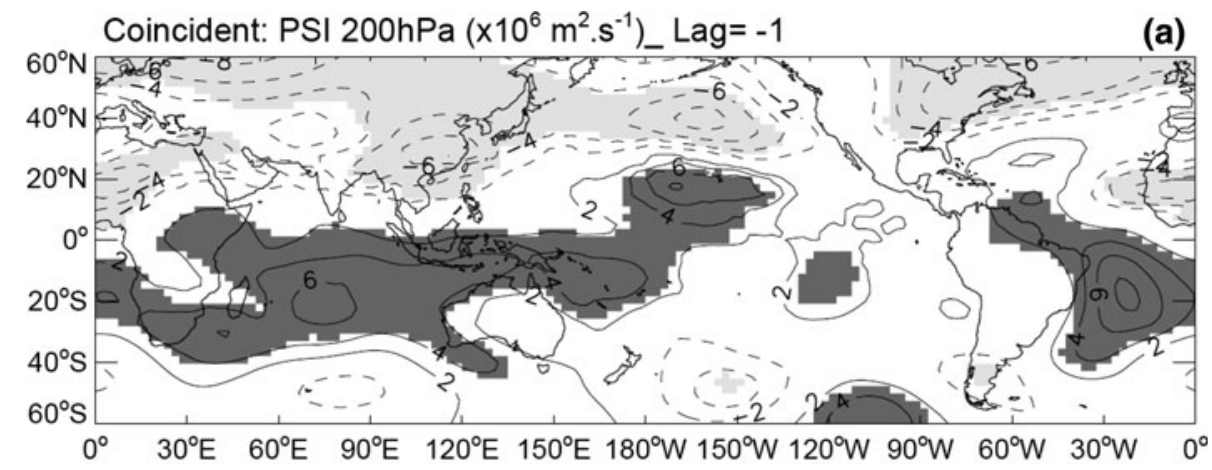

(a)

Coincident: PSI $200 \mathrm{hPa}\left(\times 10^{6} \mathrm{~m}^{2} \cdot \mathrm{s}^{-1}\right)_{-}$Lag $=0$

(b)

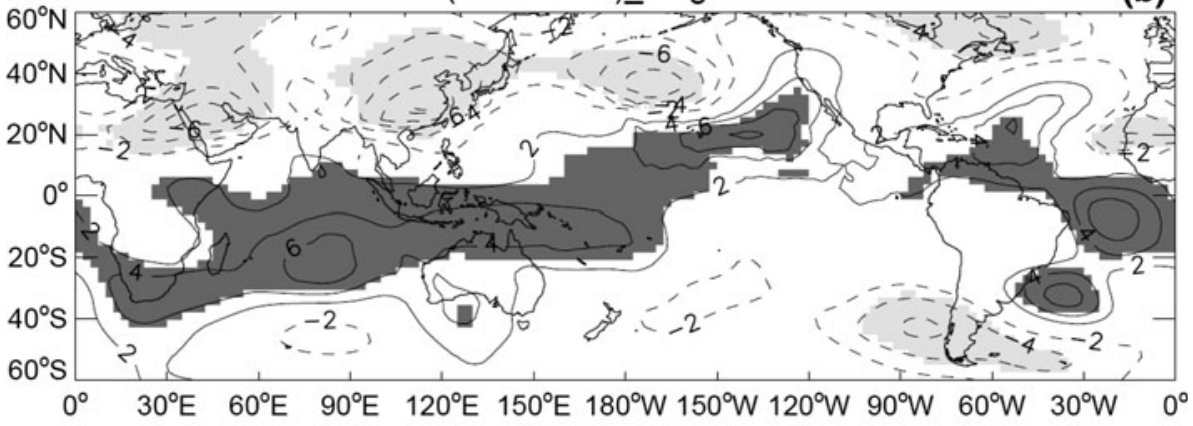

Coincident: PSI $200 \mathrm{hPa}\left(\times 10^{6} \mathrm{~m}^{2} \cdot \mathrm{s}^{-1}\right)_{-}$Lag $=1$

(c)

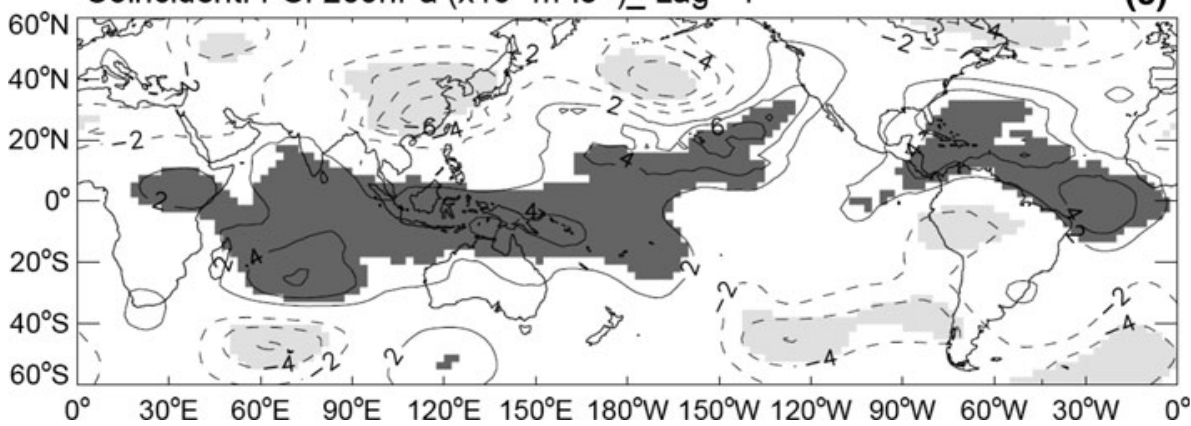

are related to high wave activity in the Southern Hemisphere in association with the PSA. In these cases, there is no evidence of enhancement in the Asian subtropical jet and of the PNA pattern. No cross-hemispheric transport of moisture is evident. Moisture from the Atlantic Ocean is transported by wind anomalies associated with wave trains.

Enhanced convection over eastern Brazil extending toward the Atlantic Ocean has been often observed (e.g. Marton and Silva Dias 2001; Carvalho et al. 2004) and was identified here from combined positive anomalies in the band-filtered LISAM and SACZ indexes. These events occur when wave activity in the Southern Hemisphere is well characterized along with the strengthening of the subtropical jet in the Northern Hemisphere. Cross-equatorial transport of humidity occurs in combination with the intensification of the transport from the western tropical Atlantic Ocean forced by anomalous cyclonic activity near the coast associated with the propagation of midlatitude wave trains. These events indicate the importance of both sources of humidity, the Amazon and the Atlantic Ocean for the enhancement of convection over eastern South America.

Acknowledgments This research was funded by NOAA Office of Global Programs (NOAA/NA05OAR4311129, NA07OAR4310211 and NA08OAR4310698). NCEP/NCAR Reanalysis data provided by the NOAA/OAR/ESRL PSD, Boulder, Colorado, USA, from their Web site at http://www.cdc.noaa.gov. Dr. Ana E. Silva thanks funding from FAPESP and CAPES. Dr. Leila M. V. Carvalho and Ana Silva thank funds from CNPq and CLARIS LPB project. Dr. Pedro L. Silva Dias acknowledges the CNPq support.

Open Access This article is distributed under the terms of the Creative Commons Attribution Noncommercial License which permits any noncommercial use, distribution, and reproduction in any medium, provided the original author(s) and source are credited. 


\section{References}

Avissar N, Silva Dias PL, Silva Dias MAF, Nobre C (2002) The large-scale biosphere-atmosphere experiment in Amazonia (LBA): insights and future research needs. J Geophys Res Atmos 107:8086. doi:8010.1029/2002JD002704

Barreiro M, Chang P, Saravanan R (2002) Variability of the South Atlantic convergence zone simulated by an atmospheric general circulation model. J Clim 15:745-763

Bombardi RJ, Carvalho LMV (2009) IPCC Global coupled climate model simulations of the South America Monsoon System. Clim Dyn 33:893-916

Carvalho LMV, Jones C, Liebmann B (2002a) Extreme precipitation events in Southeastern South America and large-scale convective patterns in the South Atlantic convergence zone. J Clim 15:2377-2394

Carvalho LMV, Jones C, Silva Dias MAF (2002b) Intraseasonal large-scale circulations and mesoscale convective activity in tropical South America during the TRMM-LBA campaign. J Geophys Res Atmos 107. doi:10.1029/2001JD000745

Carvalho LMV, Jones C, Liebmann B (2004) The South Atlantic convergence zone: intensity, form, persistence, and relationships with intraseasonal to interannual activity and extreme rainfall. J Clim 17:88-108

Casarin DP, Kousky VE (1986) Anomalias de precipitação no sul do Brasil e variações na circulação atmosférica. Rev Bras Meteorol 1:83-90

Chaves RR, Nobre P (2004) Interactions between sea surface temperature over the South Atlantic Ocean and the South Atlantic convergence zone. Geophys Res Lett 31, L03204. doi: 10.1029/2003GL018647

De Almeida RAF, Nobre P, Haarsma RJ, Campos EJD (2007) Negative ocean-atmosphere feedback in the South Atlantic convergence zone. Geophys Res Lett 34:18. doi:10.1029/ $2007 \mathrm{~g} 1030401$

Dias J, Pauluis O (2009) Convectively coupled waves propagating along an Equatorial ITCZ. J Atmos Sci 66:2237-2255

Figueroa SN, Satyamurty P, Silva Dias PL (1995) Simulations of the summer circulation over the South-American region with an Etacoordinate model. J Atmos Sci 52:1573-1584

Gan MA, Kousky VE, Ropelewski CF (2004) The South America monsoon circulation and its relationship to rainfall over WestCentral Brazil. J Clim 17:47-66

Gan MA, Rao VB, Moscati MCL (2006) South American monsoon indices. Atmos Sci Lett 6:219-223

Gandu AW, Silva Dias PL (1998) Impact of tropical heat sources on the South American tropospheric upper circulation and subsidence. J Geophys Res Atmos 103:6001-6015

Grimm AM (2003) The El Nino impact on the summer monsoon in Brazil: regional processes versus remote influences. J Clim 16:263-280

Grimm AM, Silva Dias PLD (1995) Analysis of tropical extratropical interactions with influence functions of a barotropic model. J Atmos Sci 52:3538-3555

Herdies DL, da Silva A, Silva Dias MAF, Ferreira RN (2002) Moisture budget of the bimodal pattern of the summer circulation over South America. J Geophys Res Atmos 107:8079

Horel JD, Hahmann AN, Geisler JE (1989) An investigation of the annual cycle of convective activity over the tropical Americas. J Clim 2:1388-1403

Hoskins BJ, Ambrizzi T (1993) Rossby-wave propagation on a realistic longitudinally varying flow. J Atmos Sci 50:1661-1671

Hsu H-H, Lin S-H (1992) Global teleconnections in the 250-mb streamfunction field during the Northern Hemisphere Winter. Mon Weather Rev 120:1169-1190
Jones C, Carvalho LMV (2002) Active and break phases in the South American monsoon system. J Clim 15:905-914

Jones C, Carvalho LMV (2006) Changes in the activity of the Madden-Julian oscillation during 1958-2004. J Clim 19:63536370

Jones C, Carvalho LMV (2009) Stochastic simulations of the Madden-Julian Oscillation activity. Clim Dyn. doi:10.1007/ s00382-009-0660-2

Jones C, Waliser DE, Lau KM, Stern W (2004a) Global occurrences of extreme precipitation and the Madden-Julian oscillation: observations and predictability. J Clim 17:4575-4589

Jones C, Carvalho LMV, Higgins RW, Waliser DE, Schemm JKE (2004b) Climatology of tropical intraseasonal convective anomalies: 1979-2002. J Clim 17:523-539

Kalnay E et al (1996) The NCEP-NCAR 40 year reanalysis project. Bull Am Meteorol Soc 77:437-471

Kasahara A, Silva Dias PL (1986) Response of planetary waves to stationary tropical heating in a global atmosphere with meridional and vertical shears. J Atmos Sci 43:1893-1911

Kiladis GN, Weickmann KM (1992a) Circulation anomalies associated with tropical convection during Northern Winter. Mon Weather Rev 120:1900-1923

Kiladis GN, Weickmann KM (1992b) Extratropical forcing of tropical pacific convection during Northern Winter. Mon Weather Rev 120:1924-1939

Kodama YM (1992) Large-scale common features of subtropical precipitation zones (the Baiu Frontal Zone, the SPCZ, and the SACZ). 1. Characteristics of subtropical frontal zones. J Meteorol Soc Jpn 70:813-836

Kousky VE (1979) Frontal influences on Northeast Brazil. Mon Weather Rev 107:1140-1153

Kousky VE (1988) Pentad outgoing longwave radiation climatology for the South American sector. Rev Bras Meteorol 3:217-231

Kousky VE, Ferreira NJ (1981) Interdiurnal surface pressure variations in Brazil: their spatial distribution, origins and effects. Mon Weather Rev 109:2000-2008

Lenters JD, Cook KH (1997) On the origin of the Bolivian high and related circulation features of the South American climate. J Atmos Sci 54:656-678

Liebmann B, Kiladis GN, Marengo JA, Ambrizzi T, Glick JD (1999) Submonthly convective variability over South America and the South Atlantic convergence zone. J Clim 12:1877-1891

Liebmann B, Jones C, Carvalho LMV (2001) Interannual variability of daily extreme precipitation events in the state of Sao Paulo, Brazil. J Clim 14:208-218

Liebmann B, Kiladis GN, Vera CS, Saulo AC, Carvalho LMV (2004) Subseasonal variations of rainfall in South America in the vicinity of the low-level jet east of the Andes and comparison to those in the South Atlantic convergence zone. J Clim 17:3829_ 3842

Liebmann B et al (2009) Origin of convectively coupled Kelvin waves over South America. J Clim 22:300-315

Madden RA, Julian PR (1994) Observations of the 40-50-Day tropical oscillation-A review. Mon Weather Rev 122:814-837

Marengo JA, Liebmann B, Kousky VE, Filizola NP, Wainer IC (2001) Onset and end of the rainy season in the Brazilian Amazon basin. J Clim 14:833-852

Marton E, Silva Dias PL (2001) Variabilidade Intrasazonal na Zona de Convergência do Atlântico Sul. In: Annals of the IX Congreso Latinoamericano e Iberico de Meteorologia 2001, vol 1, Buenos Aires

Misra V (2008) Coupled air, sea, and land interactions of the South American monsoon. J Clim 21:6389-6403

Mo KC, Paegle JN (2001) The Pacific-South American modes and their downstream effects. Int J Climatol 21:1211-1229 
Muza MN, Carvalho LMV, Jones C, Liebmann B (2009) Intraseasonal and interannual variability of extreme dry and wet events over Southeastern South America and subtropical Atlantic during the Austral summer. J Climate 22:1682-1699

Nogues-Paegle J, Mo KC (1997) Alternating wet and dry conditions over South America during summer. Mon Weather Rev 125:279-291

Nogues-Paegle J, Byerle LA, Mo KC (2000) Intraseasonal modulation of South American summer precipitation. Mon Weather Rev 128:837-850

North GR, Bell TL, Cahalan RF, Moeng FJ (1982) Sampling errors in the estimation of empirical orthogonal functions. Mon Weather Rev 110:699-706

Peixoto JP, Oort AH (1992) Physics of climate. American Institute of Physics, New York, 520 pp

Petersen WA, Nesbitt SW, Blakeslee RJ, Cifelli R, Hein P, Rutledge SA (2002) TRMM observations of intraseasonal variability in convective regimes over the Amazon. J Clim 15:1278-1294

Silva AE, Carvalho LMV (2007) Large-scale index for South America monsoon (LISAM). Atmos Sci Lett 8:51-57

Silva Dias PL, Marengo J (1999) Águas Doces do Brasil: Águas Atmosféricas, Capital Ecológico, Uso e Conservação. Editado por A.Rebouças, B. Braga e J. Tundizi. Instituto de Estudos Avançados e Academia Brasileira de Ciências, pp 65-115

Silva Dias PL, Schubert WH, DeMaria M (1983) Large-scale response of the tropical atmosphere to transient convection. J Atmos Sci 40:2689-2707
Straub KH, Kiladis GN (2002) Observations of a convectively coupled Kelvin wave in the eastern Pacific ITCZ. J Atmos Sci 59:30-53

Tomas RA, Webster PJ (1994) Horizontal and vertical structure of cross-equatorial wave propagation. J Atmos Sci 51:1417-1430

Vera $\mathrm{C}$ et al (2006) Toward a unified view of the American monsoon systems. J Clim 19:4977-5000

Wallace JM, Gutzler DS (1981) Teleconnections in the geopotential height field during the Northern Hemisphere winter. Mon Weather Rev 109:784-812

Wang H, Fu R (2002) Cross-equatorial flow and seasonal cycle of precipitation over South America. J Clim 15:1591-1608

Wang B, Rui H (1990) Synoptic climatology of transient tropical intraseasonal convection anomalies. Meteorol Atmos Phys 44:43-61

Webster PJ, Holton JR (1982) Cross-equatorial response to middlelatitude forcing in a zonally varying basic state. J Atmos Sci 39:722-733

Xavier TMBS, Silva Dias MAF (1995) Impact of Enso episodes on the autumn rainfall patterns near São Paulo, Brazil. Atmos Environ 15:571-584

Xie PP et al (2003) GPCP Pentad precipitation analyses: an experimental dataset based on gauge observations and satellite estimates. J Clim 16:2197-2214

Zhou JY, Lau KM (1998) Does a monsoon climate exist over South America? J Clim 11:1020-1040 